
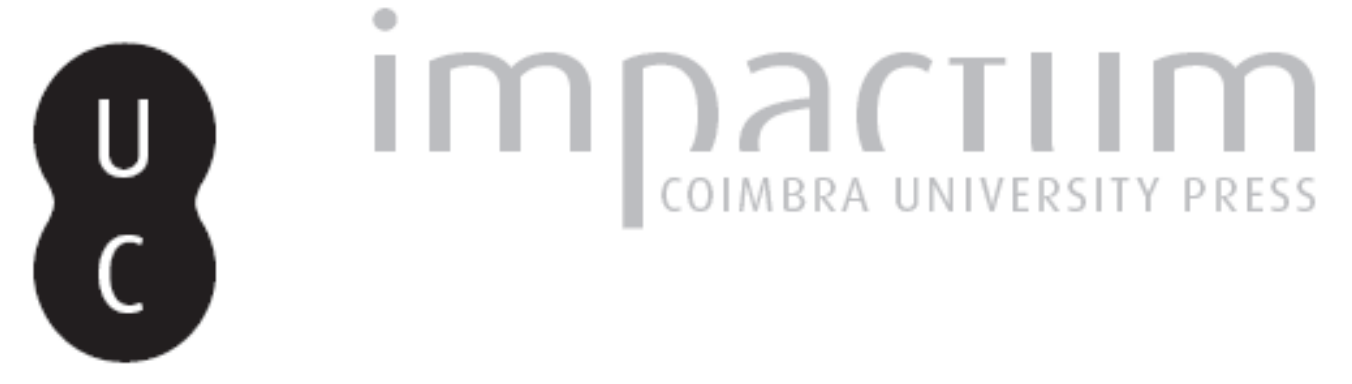

\title{
Fíbula sem mola de Santa Olaia
}

\section{Autor(es): $\quad$ Ponte, Sálete da}

Publicado por: Imprensa da Universidade de Coimbra

URL persistente:

URI:http://hdl.handle.net/10316.2/45725

DOI:

DOI:https://dx.doi.org/10.14195/1647-8657_19_5

Accessed : $\quad$ 26-Apr-2023 07:29:20

A navegação consulta e descarregamento dos títulos inseridos nas Bibliotecas Digitais UC Digitalis, UC Pombalina e UC Impactum, pressupõem a aceitação plena e sem reservas dos Termos e Condições de Uso destas Bibliotecas Digitais, disponíveis em https://digitalis.uc.pt/pt-pt/termos.

Conforme exposto nos referidos Termos e Condições de Uso, o descarregamento de títulos de acesso restrito requer uma licença válida de autorização devendo o utilizador aceder ao(s) documento(s) a partir de um endereço de IP da instituição detentora da supramencionada licença.

Ao utilizador é apenas permitido o descarregamento para uso pessoal, pelo que o emprego do(s) título(s) descarregado(s) para outro fim, designadamente comercial, carece de autorização do respetivo autor ou editor da obra.

Na medida em que todas as obras da UC Digitalis se encontram protegidas pelo Código do Direito de Autor e Direitos Conexos e demais legislação aplicável, toda a cópia, parcial ou total, deste documento, nos casos em que é legalmente admitida, deverá conter ou fazer-se acompanhar por este aviso.

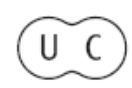


FACULDADE DE LETRAS

INSTITUTO DE ARQUEOLOGIA

CONIMBRIGA

VOLUME XIX

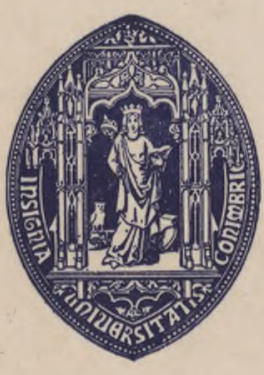

UNIVERSIDADE DE COIMBRA

1980 
Sálete da Ponte

Conservadora do Museu Monográfico de Conimbriga

FÍBULA SEM MOLA DE SANTA OLAIA

Conimbriga, XIX, 1980, 159-162

RESUMo: A autora publica urna fíbula sem mola proveniente da estação arqueológica de Santa Olaia. Paralelos só se encontraram, até agora, em Conimbriga. Relaciona-se esta fíbula com um exemplar de Falérios atribuível ao século vin a.C.

RÉSUMÉ: Une fibule sans ressort, trouvée à Santa Olaia, un oppidum de l'âge du Fer dans la basse vallée du Mondego, est identique à trois pièces trouvées à Conimbriga. Une fibule de Faleri, datée par Aberg du vm av. J.-C., est une source possible de ce type. 
(Página deixada propositadamente em branco) 


\section{FIBULA SEM MOLA DE SANTA OLAIA}

A fíbula que publicamos foi recolhida por Santos Rocha em Santa Olaia (concelho de Montemor-o-Velho) ${ }^{(2)}$ e guarda-se no Museu Municipal da Figueira da Foz (inv. n. ${ }^{\circ}$ 8239). Trata-se de uma peça de bronze, de seç̧ão circular, dobrada em L; urna das extremidades é losangonal e perfurada; aqui se articulava outra peça, igualmente em L, que servia de fusilhão; a outra extremidade apresenta, roto $\mathrm{e}$ incompleto, $\mathrm{o}$ descanso do fusilhão. Recebeu recentemente tratamento adequado no laboratório do Museu Monográfico de Gonimbriga; após a limpeza mecânica sob uma lupa binocular, foi impregnada no vácuo com Benzotriazol e protegida com verniz Incralac adicionado de Santocel. Foi então que reparámos que a haste em $\mathrm{L}$ não era senão um exemplar incompleto do tipo de fíbula «sem mola»( $\left.{ }^{2}\right)$. Para a reconstituição da fíbula de Santa Olaia, servimo-nos de um modelo completo de Gonimbriga, proveniente das escavações de 1965 ( $\left.{ }^{3}\right) .{ }^{\text {I }}$

I1) António dos Santos Rocha, Estações Pré-Romanas da Idade do

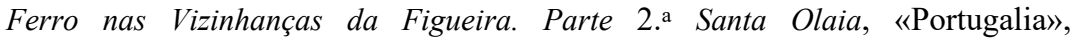
Vol. II, fase. 3, Lisboa, 1905-08, p. 310-354, p. 331, est. XX, n. ${ }^{\circ} 60$. O autor desconhece a sua utilidade, embora reconheça que outra peça se lhe associa; idem, Memórias e Explorações Arqueológicas. Estações pré-romanas da Idade do Ferro nas vizinhanças da Figueira, «Acta Universitatis Conimbrigensis», Yol. II, Coimbra, 1971, p. 53.

(2) Sálete da Ponte, Fíbulas Pré-Romanas e Romanas de Conimbriga, «Conimbriga», vol. XII, Coimbra, 1973, p. 159-197, p. 165-166; А. Moutinho Alarcão E S. Da Ponte, Les objects de parure et de toilette. Les instruments de chirurgie, in Fouilles de Conimbriga, vol. VII, París, 1979 (= Fouilles de Conimbriga VII), p. 109-126.

(3) Fouilles de Conimbriga VII, p. ${ }_{110}$, Est. XXIV, n. ${ }^{\circ}{ }_{1}$ 
Ao contrário dos três exemplares achados em Conimbriga, o de Santa Olaia é decorado com sete grupos de incisões dispostos transversalmente e distanciados entre si. Pela construção deste tipo, não temos dúvidas em integrá-lo na $1 .{ }^{\mathrm{a}}$ Idade do Ferro, apesar da carência de dados estratigráficos seguros. Conhecemos, porém, um paralelo encontrado em Falérios que Aberg data do séc. viu a.C. $\left({ }^{4}\right)$.

Fica em aberto a questão da origem dos exemplares deste tipo encontrados em Portugal: tratar-se-á de um fabrico autóctone ou de importação? Os exemplares até agora encontrados em Portugal provêm de Santa Olaia e de Conimbriga, estações que mantiveram indiscutíveis contactos com as feitorias púnicas peninsulares.

SÁlete da Ponte

(4) Sálete da Ponte, op. cit., p. 165-166 e Fouilles de Conimbriga VII, p. 110 .

Conimbriga, 19 (1980), 159-162 


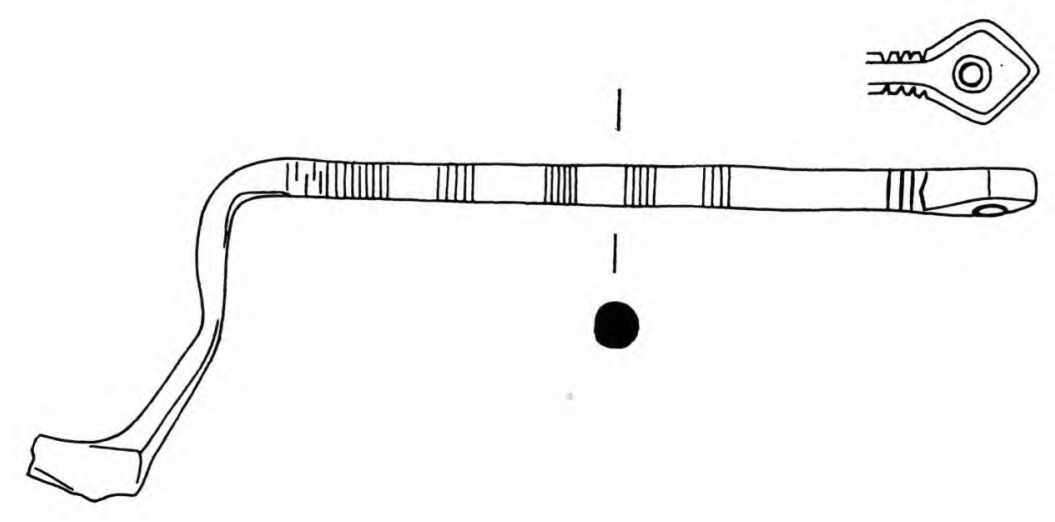

